\title{
Vacuolar Invertases in Sweet Potato: Molecular Cloning, Characterization, and Analysis of Gene Expression ${ }^{\dagger}$
}

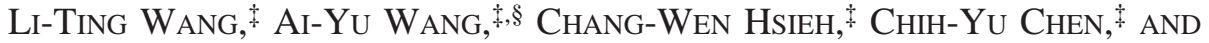 \\ HSIEN-Yi SUNG $*,+, \S$
}

Institute of Microbiology and Biochemistry and Department of Biochemical Science and Technology,

National Taiwan University, Taipei 106, Taiwan

\begin{abstract}
Two cDNAs (Ib/fruct2 and Ib $\beta$ fruct3) encoding vacuolar invertases were cloned from sweet potato leaves, expressed in Pichia pastoris, and the recombinant proteins were purified by ammonium sulfate fractionation and chromatography on Ni-NTA agarose. The deduced amino acid sequences encoded by the cDNAs contained characteristic conserved elements of vacuolar invertases, including the sequence $R[G / A / P] x x x G V S[E / D / M] K[S / T / A / R]$, located in the prepeptide region, $W x x x[M / I / V] L x W Q$, located around the starting site of the mature protein, and an intact $\beta$-fructosidase motif. The $\mathrm{pH}$ optimum, the substrate specificity, and the apparent $K_{\mathrm{m}}$ values for sucrose exhibited by the recombinant proteins were similar to those of vacuolar invertases purified from sweet potato leaves and cell suspensions, thus confirming that the proteins encoded by $1 \mathrm{~b} \beta$ fruct 2 and lb $\beta$ fruct 3 are vacuolar invertases. Moreover, northern analysis revealed that the expression of the two genes was differentially regulated. With the exception of mature leaves and sprouting storage roots, Ib $\beta$ fruct $2 \mathrm{mRNA}$ is widely expressed among the tissues of the sweet potato and is more abundant in young sink tissues. By contrast, Ib $\beta$ fruct 3 mRNA was only detected in shoots and in young and mature leaves. It appears, therefore, that these two vacuolar invertases play different physiological roles during the development of the sweet potato plant.
\end{abstract}

KEYWORDS: Vacuolar invertase; cDNA; sweet potato (Ipomoea batatas); recombinant invertase; Pichia pastoris; gene expression

\section{INTRODUCTION}

The sweet potato Ipomoea batatas $\mathrm{L}$. is a dicotyledonous plant that belongs to the family Convolvulaceae. The major part of the plant used as human food is its storage root (tuberous roots), which is rich in starch and dietary fiber and is a good source of vitamin $\mathrm{A}$; indeed, $100 \mathrm{~g}$ of cooked sweet potatoes provides about $11.5 \mathrm{mg}$ of $\beta$-carotene or about four times the U.S. recommended daily allowance (1). The plant is also used as animal feed and for starch extraction. In addition, the leaves of sweet potato are eaten as a green vegetable in parts of Asia (2, 3).

Sweet potato production is affected by several internal and external factors, including the net photosynthetic rate, photosynthate partition, storage root sink potential, temperature, moisture level, and pathogens $(3,4)$. It has been proposed that in many plants the sucrose-cleaving enzymes invertase and sucrose synthase play key roles in the control of the photosynthate partition and in the determination of the sink strength $(5-8$

The nucleotide sequences reported in this paper have been submitted to GenBank under the accession numbers AY037937 and AY037938.

* To whom correspondence should be addressed. Tel/Fax: +886-223634729. E-mail: sunghy@ntu.edu.tw.

Institute of Microbiology and Biochemistry.

$\S$ Department of Biochemical Science and Technology. and references therein). Invertase hydrolyzes sucrose into fructose and glucose, whereas sucrose synthase converts sucrose and UDP into fructose and UDP-glucose. Both enzymes have been purified from sweet potato, and their in situ activities have been well-studied $(9-12)$.

As a group, the invertases are $\beta$-fructofuranosidases that have been categorized as cytoplasmic, vacuolar, and cell wallassociated forms based on their solubility properties, subcellular localizations, and pH optima (5). The cytoplasmic form (neutral/ alkaline invertase) exhibits optimal activity within a $\mathrm{pH}$ range of 7.0-8.0, whereas both the vacuolar (soluble acid invertase) and the cell wall-associated (extracellular acid invertase) forms exhibit optimal activity at acidic $\mathrm{pH}$ values. Functionally, the cytoplasmic enzyme is probably involved in channeling sucrose into catabolism, while the proposed functions of the cell wallassociated enzyme include sucrose partitioning between source and sink organs and regulation of cell differentiation, plant development, and the responses to signals from various biotic and abiotic stresses. Vacuolar invertases have been proposed to play important roles in osmoregulation and cell enlargement, in the regulation of the sugar composition in fruits and storage organs, and in the response to cold (6-8 and references therein).

In the previous studies, we have characterized several invertase isoforms and have cloned a cDNA encoding vacuolar 
invertase from sweet potato $(10,13,14)$. In this paper, we report the cloning of two other vacuolar invertase cDNAs and the functional expression of their encoded proteins in Pichia pastoris. To gain insight into the functions of the different vacuolar invertases in the sweet potato, the expression of the two invertase genes was analyzed by northern hybridization. The results revealed the differentially regulated expression of the two invertase genes and suggested different physiological roles of the different isozymes.

\section{MATERIALS AND METHODS}

Plant Materials. Sweet potato (I. batatas L. cv. Tainong 57) plants were grown in a field in natural light. Leaves and storage roots were collected at various developmental stages, immediately frozen in liquid nitrogen, and stored at $-80{ }^{\circ} \mathrm{C}$ until required.

RNA Isolation. The frozen sweet potato samples were ground into a fine powder in liquid nitrogen, after which total RNA was isolated using Trizol reagent (Invitrogen, Carlsbad, CA) according to the manufacturer's instructions. Poly(A) ${ }^{+}$RNA was purified from the total RNA using biotinylated-oligo(dT) with a PolyATract mRNA Isolation System (Promega, Madison, WI).

Cloning of Invertase cDNA. A cDNA library was constructed from poly $(\mathrm{A})^{+}$-RNA isolated from leaves at different developmental stages using a SuperScript Choice System (Invitrogen) and a Lamba ZAP II RI Library Construction Kit (Stratagene, La Jolla, CA). A 1.4 kb sweet potato invertase cDNA fragment (13) was first ${ }^{32} \mathrm{P}$-labeled using the random primer method with a Rediprime DNA Labeling System (Amersham Biosciences, Buckinghamshire, United Kingdom) and then used as a probe to screen the cDNA library. The positive plaques were isolated and subjected to in vivo excision of the pBluescript SKphagemids from the lambda ZAP II vector.

DNA Sequencing and Sequence Analysis. Both DNA strands were sequenced using an ABI PRISM BigDye Terminator Cycle Sequencing Ready Reaction Kit with an ABI 3730 XL DNA Analyzer (Applied Biosystems, Foster City, CA). The nucleotide and protein sequence analyses were using the programs of Wisconsin Package Version 10.1 (Accelrys Inc., San Diego, CA). The cleavage site for the leader sequence was predicted by the SPScan program of Wisconsin Package and comparison with other vacuolar invertases.

Preparation of Gene Specific Probes. The DNA probe specific for $I b \beta f r u c t 2$ was synthesized by polymerase chain reaction (PCR) using the cDNA as a template and gene specific primers selected from the 3'-untranslated region (3'-UTR) [forward, 5'-CTTGGATGAGTTGTAGTTCCA-3' (nucleotides 2001-2021); reverse, 5'-GGGGATACTTGTAAACTCATC-3' (nucleotides 2180-2196; the underlined nucleotides were added to adjust the GC content)]. The identity of the amplified DNA fragment was confirmed by sequencing. For Ib $\beta$ fruct 3 , the entire Ib $\beta$ fruct $3-1$ cDNA was used as a probe. The DNA probe for $18 \mathrm{~S}$ rRNA was a $1.6 \mathrm{~kb}$ DNA fragment containing part of the rice $18 \mathrm{~S}$ rRNA gene, which was amplified from rice genomic DNA (15). For use in the northern hybridization, the Ib $\beta$ fruct 2 specific probe was labeled with $\left[\alpha_{-}{ }^{32} \mathrm{P}\right] \mathrm{dATP}$ (NEN, Boston, MA) by PCR, while the Ib $\beta$ fruct 3 specific and $18 \mathrm{~S}$ rRNA specific probes were labeled with $\left[\alpha-{ }^{32} \mathrm{P}\right] \mathrm{dCTP}(\mathrm{NEN})$ using the random primer method.

Northern Analysis. Twenty micrograms of total RNA from each sample was separated on $1.2 \%(\mathrm{w} / \mathrm{v})$ agarose gels containing formaldehyde (16) and then transferred onto positively charged nylon membranes (Immobilon-Ny+, Millipore, Bedford, MA). Following hybridization, the blots were washed twice for $10 \mathrm{~min}$ at room temperature with $2 \times$ SSPE and $0.1 \%$ sodium dodecyl sulfate (SDS), once for 15 min at $42{ }^{\circ} \mathrm{C}$ with $1 \times \mathrm{SSPE}$ and $0.1 \% \mathrm{SDS}$, and then once for $15 \mathrm{~min}$ at $62{ }^{\circ} \mathrm{C}$ with $0.1 \times$ SSPE and $0.1 \%$ SDS for the Ib fruct 2 and Ib $\beta$ fruct 3 probes or at $65{ }^{\circ} \mathrm{C}$ for the $18 \mathrm{~S}$ rRNA probe. The blots were then exposed to phosphorimaging plates, and the captured imagines were analyzed using a Bio Imaging Analyzer (Fujix BAS1000, Fuji Photo Film, Tokyo, Japan).

Production and Purification of Recombinant Invertases in Yeast. The coding regions of Ib $\beta$ fruct 2 and Ib $\beta$ fruct 3 without the putative leader sequences were amplified by PCR. The sequences of the primers were 5'-AAATCGATGTCCGGCGCCGGCAAT-3' (forward primer for Ib $\beta$ fruct2, nucleotides 355-369), 5'-GGTCTAGAAACAACTCATCCAAGGG-3' (reverse primer for Ib/fruct2, nucleotides 1999-2014), 5'-AAGGAATTCATGTCCGGCGGTCGGATTT-3' (forward primer for Ib/fruct3, nucleotides 339-355), and 5'-GGGGGTTCTAGAAACAATTGATTGATGA-3' (reverse primer for Ib/fruct 3 , nucleotides 1969-1984). The underlined nucleotides shown in the forward primers were added to incorporate the translation initiation codon and restriction sites (ClaI and EcoRI for Ib $\beta f r u c t 2$ and Ib $\beta f r u c t 3$, respectively), and those in the reverse primers were added for incorporation of $X b a \mathrm{I}$ site. The amplified Ib/fruct 2 DNA fragment was digested with $C l a \mathrm{I}$ and

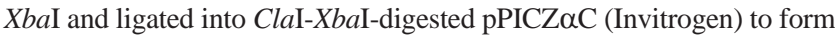
pIT2-M. The amplified Ib $\beta$ fruct3 DNA fragment was digested with $E c o$ RI and $X b a \mathrm{I}$ and ligated into plasmid pPICZ $\alpha \mathrm{A}$ that had been digested with the same restriction enzymes, yielding pIT3-M. To express recombinant invertases in yeast, $P$. pastoris strain X-33 was transformed with pIT2-M or pIT3-M using a Pichia EasyComp Kit (Invitrogen). Growth of the transformed cells and induction of expression with methanol were carried out as described previously (13), except that the induction time was $24 \mathrm{~h}$.

Purification of the recombinant enzymes was carried out at $0-4$ ${ }^{\circ} \mathrm{C}$. The methanol-induced cultures were centrifuged for $5 \mathrm{~min}$ at $6000 \mathrm{~g}$, after which solid ammonium sulfate was added to the supernatant. Proteins fractionated by $35-65 \%$ saturation with ammonium sulfate were pelleted by centrifugation, dissolved in PB $8.0(50 \mathrm{mM}$ sodium phosphate, $\mathrm{pH} 8.0$ ), and dialyzed with the same buffer. The resultant enzyme solution was mixed with a suspension of Ni-NTA agarose [50\% $(\mathrm{v} / \mathrm{v})$ in equilibrium buffer $(50 \mathrm{mM}$ sodium phosphate, $\mathrm{pH} 8.0,150$ $\mathrm{mM} \mathrm{NaCl}, 5 \mathrm{mM}$ imidazole, $0.1 \%$ Triton X-100, $20 \mathrm{mM} \beta$-mercaptoethanol)] and then incubated for $1 \mathrm{~h}$ at $4{ }^{\circ} \mathrm{C}$. The enzyme-Ni-NTA agarose mixture was then packed into a column, washed with buffer $\mathrm{A}$ (50 mM sodium phosphate, $\mathrm{pH} 8.0,100 \mathrm{mM} \mathrm{NaCl}, 10 \mathrm{mM}$ imidazole, $0.1 \%$ Triton $\mathrm{X}-100$, and $20 \mathrm{mM} \beta$-mercaptoethanol), and then eluted with buffer B (50 mM sodium phosphate, $\mathrm{pH} 8.0,300 \mathrm{mM} \mathrm{NaCl}, 250$ $\mathrm{mM}$ imidazole, $0.1 \%$ Triton X-100, and $20 \mathrm{mM} \beta$-mercaptoethanol). Fractions showing invertase activity were collected.

Enzyme Assay and Protein Analytic Methods. The invertase activity was assayed at pH 5.0 as described by Sung and Huang (17). The amount of reducing sugar produced was measured using the method of Somogyi-Nelson (18). The protein concentration was determined using the protein dye binding method (19), with bovine serum albumin serving as the standard protein. Enzymatic deglycosylation of the recombinant invertase rIT2 by N-glycosidase F (PNGase F, Roche Applied Science, Mannheim, Germany) was performed as described previously (13) except that the incubation time was $16 \mathrm{~h}$. To complete deglycosylation of the recombinant invertase rIT3, the enzyme was heated at $100{ }^{\circ} \mathrm{C}$ for $10 \mathrm{~min}$ in the presence of $1 \%$ SDS before PNGase $\mathrm{F}$ was added. SDS-polyacrylamide gel electrophoresis (PAGE) was carried out according to the method of Laemmli (20). The protein bands in gels were stained with Coomassie Blue R-250 or silver nitrate.

\section{RESULTS AND DISCUSSION}

Isolation and Characterization of Invertase cDNA Clones from Sweet Potato Leaves. We previously cloned a cDNA (Ib $\beta$ fruct1) encoding vacuolar invertase from the sink leaves of the sweet potato (13). Northern analysis using the $3^{\prime}$-UTR of Ib $\beta$ fruct 1 as a gene specific probe indicated that Ib $\beta$ fructI mRNA was more abundant in sink leaves than in either source leaves or storage roots. Nevertheless, when the northern blots were hybridized with a probe containing a sequence conserved among plant vacuolar invertases, similar levels of invertase mRNA in sink leaves, source leaves, and storage roots were observed (21). This suggested that at least two isoforms of vacuolar invertase are expressed in sweet potato. To isolate other cDNA clones encoding invertase, a cDNA library was constructed using mRNA collected from leaves at various stages in their growth. By screening the cDNA library with a sweet potato invertase probe containing the conserved region of plant 


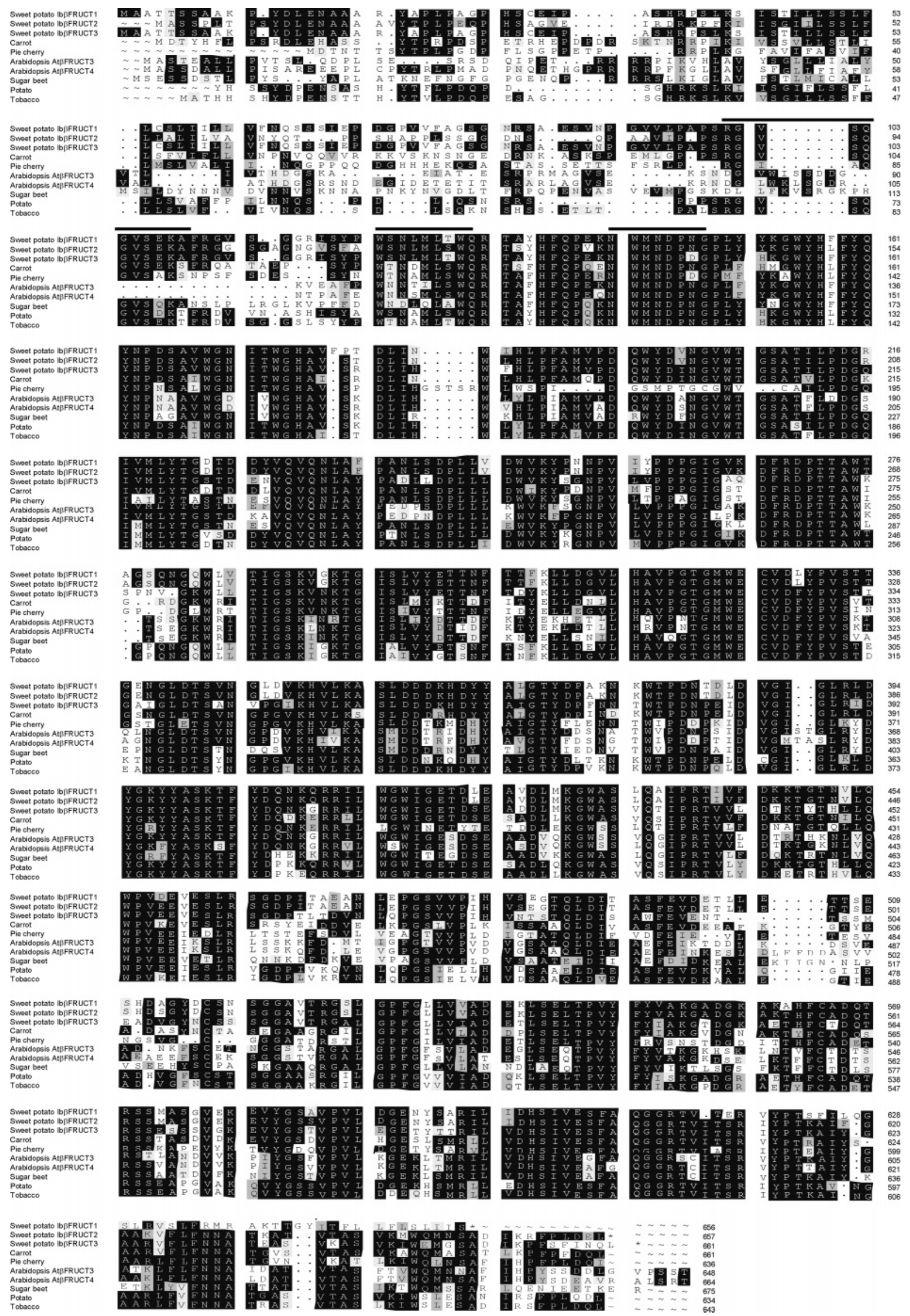

Figure 2. Alignment of the deduced amino acid sequences derived from Ib $\beta$ fruct cDNAs and vacuolar invertase cDNAs from other dicot plants. The sequences compared are from carrot (Daucus carota, CAA53097.1), pie cherry (P. cerasus, AAL05427.2), Arabidopsis thaliana (At $\beta$ FRUCT3, NP_567498.1; At $\beta$ FRUCT4, NP_567901.1), sugar beet (Beta vulgaris, CAD19321.1), potato (Solanum tuberosum, CAA49831.1), and tobacco (Nicotiana tabaccum, CAC83577.2). The characteristic conserved elements of vacuolar invertases are indicated by lines above the sequences. 
(A)

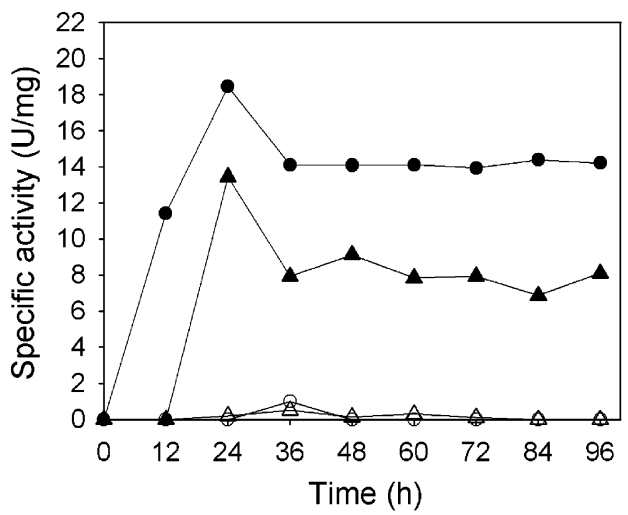

(B)

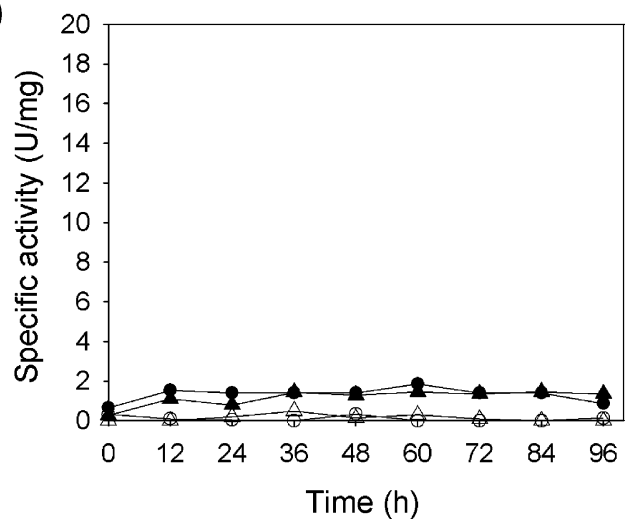

Figure 3. Expression of recombinant invertases in $P$. pastoris. Cells transformed with pIT2-M (⿶), pIT3-M $(\mathbf{\Delta}), \operatorname{pPICZ} \alpha \mathrm{C}(\mathrm{O})$, or pPICZ $\alpha \mathrm{A}$ $(\triangle)$ were grown in media without methanol at $30^{\circ} \mathrm{C}$ until $A_{600}$ values reached 2.0, after which expression of recombinant proteins was induced by adding methanol to the cultures (13). Samples collected at various times after induction were centrifuged at $3000 \mathrm{~g}$ for $5 \mathrm{~min}$. Proteins secreted into the culture medium $(\mathbf{A})$ and in the intracellular fraction $(\mathbf{B})$ were assayed for invertase activity at $\mathrm{pH}$ 5.0.

two residues in the $\beta$-fructosidase motif of the latter were DG instead of NG, which has also been noted in vacuolar invertases from pie cherry (Prunus cerasus, accession number AAL05427.2) and tulip (Tulipa gesneriana, accession number CAA64953). The presence of the three characteristic elements confirmed that Ib $\beta$ fruct 2 and Ib $\beta$ fruct 3 encode vacuolar type acid invertases and not cell wall-associated acid invertases or fructanmetabolizing fructosyltransferases.

Expression and Characterization of the Ib/fruct2- and Ib/fruct3-Encoded Proteins in Yeast. To express the Ib $\beta$ fruct2and Ib $\beta$ fruct 3 -encoded proteins, $P$. pastoris cells were, respectively, transformed with the expression plasmids pIT2-M and pIT3-M. The putative mature proteins, which contained a c-myc epitope and a His tag fused at their $\mathrm{C}$ terminus, were expected to be expressed under the control of the alcohol oxidase (AOX1) promoter and to be secreted into the culture medium via a yeast $\alpha$-factor secretion signal. Consistent with that expectation, when the transformed cells were grown in the presence of methanol, the acid invertase activity accumulated in the growth medium (Figure 3), such that the activity in the intracellular fraction was only about $10 \%$ of that in the growth medium. Table 1 shows the results of the purification using ammonium sulfate fractionation and chromatography on Ni-NTA agarose of the recombinant Ib $\beta$ fruct 2 - and Ib $\beta$ fruct3-encoded proteins (designated rIT2 and rIT3, respectively) from the conditioned media of transformed $P$. pastoris cells. This two step protocol was sufficient to remove most of the impurities from the samples (Figure 4).
Table 1. Purification of the Recombinant Invertases rIT2 and rIT3 from Transformed P. pastoris ${ }^{a}$

\begin{tabular}{|c|c|c|c|c|c|c|}
\hline $\begin{array}{l}\text { purification } \\
\text { step }\end{array}$ & enzyme & $\begin{array}{c}\text { total } \\
\text { activity } \\
\left(\text { units }^{b}\right)\end{array}$ & $\begin{array}{l}\text { total } \\
\text { protein } \\
\text { (mg) }\end{array}$ & $\begin{array}{c}\text { specific } \\
\text { activity } \\
\text { (units/mg) }\end{array}$ & $\begin{array}{l}\text { yield } \\
(\%)\end{array}$ & $\begin{array}{l}\text { purification } \\
\text { (fold) }\end{array}$ \\
\hline \multirow{2}{*}{$\begin{array}{l}\text { centrifugal } \\
\text { supernatant } \\
\text { of the culture }\end{array}$} & rlT2 & 578 & 7.9 & 73 & 100 & 1.0 \\
\hline & rlT3 & 140 & 9.7 & 14 & 100 & 1.0 \\
\hline \multirow{2}{*}{$\begin{array}{l}\text { ammonium } \\
\text { sulfate } \\
\text { fractionation }\end{array}$} & rlT2 & 377 & 6.9 & 55 & 65 & 0.8 \\
\hline & rIT3 & 101 & 8.3 & 12 & 72 & 1.9 \\
\hline Ni-NTA & rlT2 & 166 & 0.3 & 553 & 29 & 7.6 \\
\hline agarose & rlT3 & 7 & 0.1 & 70 & 5 & 5.0 \\
\hline
\end{tabular}

${ }^{a}$ The data were obtained from the centrifugal supernatant of a $500 \mathrm{~mL}$ culture of methanol-induced $P$. pastoris transformed with pIT2-M or plT3-M. ${ }^{b}$ One unit of invertase was defined as the amount of enzyme that catalyzed the formation of 1 $\mu \mathrm{mol}$ of reducing sugar from sucrose per minute at $37^{\circ} \mathrm{C}$ and $\mathrm{pH} \mathrm{5.0.}$

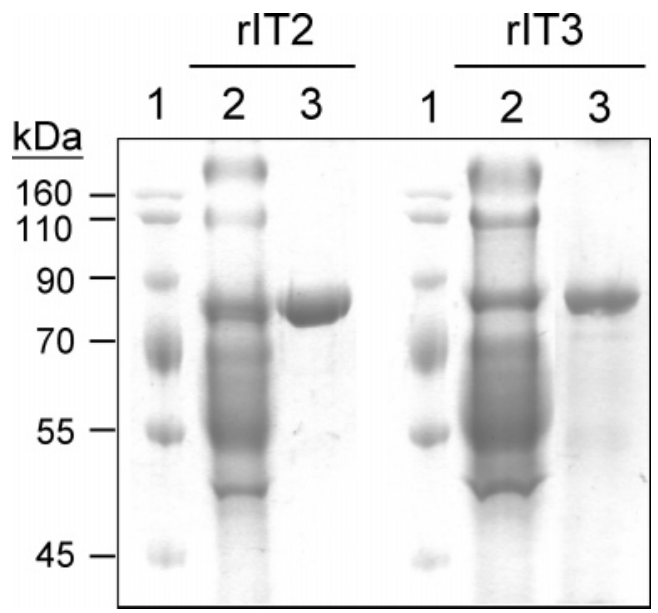

Figure 4. Purification of the recombinant invertases rIT2 and rIT3. Protein samples collected at various stages of the purification were separated on $10 \%$ SDS-polyacrylamide gels, which were then stained with Coomassie blue R-250. Lane 1, molecular mass markers; lane 2, proteins precipitated by ammonium sulfate (35-65\%); and lane 3, proteins purified by Ni-NTA agarose chromatography.

Table 2. Substrate Specificity of the Recombinant Invertases rIT2 and rIT3

\begin{tabular}{lcc}
\hline & \multicolumn{2}{c}{ relative activity $(\%)$} \\
\cline { 2 - 3 } \multicolumn{1}{c}{ substrate } & $\mathrm{rIT}$ & $\mathrm{rlT3}$ \\
\hline sucrose $(0.1 \mathrm{M})$ & 100 & 100 \\
raffinose $(0.1 \mathrm{M})$ & $37 \pm 1$ & $25 \pm 3$ \\
stachyose $(0.1 \mathrm{M})$ & $13 \pm 3$ & $9 \pm 2$ \\
cellobiose $(0.1 \mathrm{M})$ & 0 & 0 \\
maltose $(0.1 \mathrm{M})$ & 0 & 0 \\
lactose $(0.1 \mathrm{M})$ & 0 & 0 \\
inulin $(2 \%)$ & 0 & 0 \\
\hline
\end{tabular}

Both rIT2 and rIT3 exhibited a pH optimum of 5.0, with activities declining sharply at higher $\mathrm{pH}$ values (data not shown). In addition to sucrose, the two recombinant enzymes also hydrolyzed raffinose and stachyose, although the activities were substantially lower than with sucrose (Table 2) and neither enzyme displayed any activity with cellobiose, maltose, lactose, or inulin. The $\mathrm{pH}$ optimum and substrate specificity exhibited by the recombinant proteins are consistent with vacuolar invertases purified from sweet potato leaves (10) and cell suspensions (14). Moreover, the apparent $K_{\mathrm{m}}$ values obtained for rIT2 and rIT3 with sucrose (4.97 and $10.1 \mathrm{mM}$, respectively) 
rIT2

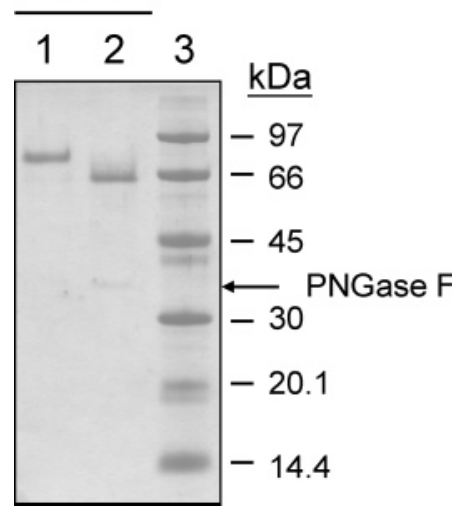

Figure 5. Analysis of the deglyosylated recombinant invertases rIT2 and rlT3. Purified rIT2 and rIT3 were incubated with PNGase $\mathrm{F}$ at $37^{\circ} \mathrm{C}$ for $16 \mathrm{~h}$ and then separated on $12.5 \%$ SDS-PAGE. The resolved proteins were stained with Coomassie blue R-250 (left panel) or silver nitrate (right panel). Lane 1, purified recombinant invertase; lane 2, purified recombinant invertase treated with PNGase F; and lane 3, molecular mass markers.

were situated between those for the enzymes purified from leaves $(3.05 \mathrm{mM})$ and from cell suspensions $(17.6 \mathrm{mM})$. Thus, the identity of rIT2 and rIT3 as vacuolar invertases was further confirmed by their functionality.

The N-terminal sequences of rIT2 and rIT3 determined by Edman degradation were SGAGNGVS (amino acid residues 105-112 of the cDNA-derived sequence) and SGGRRISY (114-121), respectively. The results were consistent with the expected sequences for the predicted mature proteins. The molecular masses of the purified rIT2 and rIT3 estimated by SDS-PAGE were approximately 82 and $87 \mathrm{kDa}$, respectively. These values are higher than the calculated molecular masses for the two recombinant enzymes and also higher than those of the enzymes purified from leaves $(61 \mathrm{kDa}, 10)$ and cell suspensions $(63 \mathrm{kDa}, 14)$. To examine whether the differences in molecular mass were due to glycosylation of the recombinant enzymes, the purified rIT2 and rIT3 were subjected to deglycosylation with PNGase F (Figure 5). The observed molecular masses of the two deglycosylated enzymes were both about 66 $\mathrm{kDa}$, which are very close to the calculated molecular masses for the c-myc epitope and His tag fused recombinant enzymes (64.03 and $63.29 \mathrm{kDa}$, respectively). The result indicated that the extent of glycosylation is different in $P$. pastoris and in sweet potato.

Expression of Ib/fruct2 and Ib/fruct3 Genes in Sweet Potato. The expression of the two Ib $\beta$ fruct genes in sweet potato was examined by northern analysis. The hybridization probe specific for Ib $\beta$ fruct 2 was a DNA fragment containing the $3^{\prime}$ UTR of the gene. For Ib $\beta$ fruct3, on the other hand, we used the entire Ib $\beta$ fruct $3-1$ cDNA as the hybridization probe because the lengths and sequences of the 3'-UTRs differed among the three Ib $\beta$ fruct 3 clones. Although the specificity of the Ib $\beta$ fruct 3 probe was verified by cross-Southern hybridization with fulllength Ib $\beta$ fruct 2 and Ib $\beta$ fruct 3 cDNAs (data not shown), the presence of other vacuolar invertase genes that are highly homologous to Ib $\beta$ fruct 3 cannot be ruled out. Consequently, the result obtained using the Ib $\beta$ fruct $3-1$ cDNA probe may not reflect exclusively the gene expression of Ib $\beta f r u c t 3$.

The observed differences in the hybridization patterns of the two probes revealed that the expression of the two genes is differentially regulated (Figure 6). Levels of Ib $\beta$ fruct $2 \mathrm{mRNA}$ were higher in sprouting shoots, immature leaves, stems, and storage roots than in fibrous roots but were barely detected in

\section{Leaves \\ Storage roots \\ Sh S M L St FR S L Sp}

Ib $\beta$ fruct2

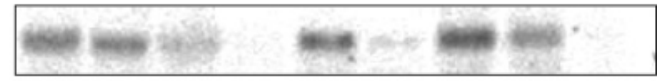

Ib fruct3

$18 \mathrm{~S}$ rRNA

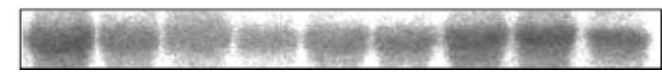

Figure 6. Expression of $I b \beta$ fruct 2 and $I b \beta$ fruct3 in sweet potato. Total RNA was isolated from sprouting shoots (Sh), small leaves $(S, 2 \mathrm{~cm}$ in length), middle-sized leaves (M, $5 \mathrm{~cm}$ in length), large leaves $(L, 9 \mathrm{~cm}$ in length), stems (St), fibrous roots (FR), small storage roots $(S, 6 \mathrm{~cm}$ in length), large (mature) storage roots (L, $16 \mathrm{~cm}$ in length), and sprouting storage roots (Sp). An equal amount of RNA $(20 \mu \mathrm{g})$ was loaded into each lane of a formaldehyde agarose gel and analyzed by northern blot hybridization. Identical blots were hybridized with Ib $\beta$ fruct2 specific, Ib $\beta$ fruct3 specific, and 18S rRNA specific probes.

mature leaves and sprouting storage roots. Vacuolar invertases are thought to play an important role during sink initiation and the initial expansion growth of many sinks ( 8 and references therein). The presence of high levels of Ib $\beta$ fruct 2 mRNA in young sink tissues is consistent with such a function. In contrast to the wide distribution of Ib $\beta$ fruct 2 mRNA, the transcripts detected using the Ib $\beta$ fruct 3 probe were restricted to the shoots and leaves. Furthermore, the changes in the levels of the two gene transcripts during the maturation of the leaves differed. Levels of Ib $\beta$ fruct 2 mRNA were highest in shoots and then gradually declined until they were undetectable in large (mature) leaves. By contrast, levels of Ib $\beta$ fruct 3 mRNA were low in shoots and at a maximum in small leaves, although a significant amount of Ib $\beta$ fruct 3 mRNA was still present in mature leaves. Expression of the two genes thus appears to be developmentally regulated during maturation of the leaves. Notably, the temporal and spatial patterns of the Ib $\beta$ fruct 3 -encoded enzyme suggest that, in addition to functioning during the cell expansion of young leaves, it may play a role in the storage of photosynthate in the vacuoles of mature leaves.

In summary, our results reveal that the vacuolar invertases in sweet potato are encoded by at least three genes. Expression of Ib $\beta$ fruct 2 and Ib $\beta$ fruct 3 in sweet potato is both spatially and temporally regulated. The differential expression of the two genes suggests that different vacuolar invertases play different physiological roles during the development of the sweet potato plant. The Ib $\beta$ fruct 2 - and Ib $\beta$ fruct 3 -encoded proteins were successfully overexpressed and purified from $P$. pastoris. The recombinant proteins exhibited similar biochemical properties to the vacuolar invertases purified from sweet potato. The results not only confirm the identity of Ib $\beta$ fruct 2 and Ib $\beta$ fruct 3 as vacuolar invertase genes but also indicate that the heterologous expression system together with the two-step easy purification procedure is a highly feasible system to study the structurefunction relationships, regulatory and mechanistic properties, and industrial applications of the enzyme.

\section{LITERATURE CITED}

(1) U.S. Department of Agriculture, Agricultural Research Service. USDA Nutrient database for standard reference, release 17 Nutrient Data Laboratory Home Page, http://www.nal.usda.gov/ fnic/foodcomp, 2004. 
(2) Woolfe, J. A. Sweet potato-past and present. In Sweet Potato: An Untapped Food Resource; Cambridge University Press: Cambridge, 1992; pp 15-40.

(3) Jansson, R. K.; Raman, K. V. Sweet potato pest management: A global overview. In Sweet Potato Pest Management: A Global Perspective; Jansson, R. K., Raman, K. V., Eds; Westview Press: Boulder, Colorado, 1991; pp 1-12.

(4) Kays, S. J.; Magnuson, C. E.; Fares, Y. Assimilation patterns of carbon in developing sweet potatoes using ${ }^{11} \mathrm{C}$ and ${ }^{14} \mathrm{C}$. In Sweet Potato. Proceedings of the First International Symposium; Villareal, R. L., Griggs, T. D., Eds; Asian Vegetable Research and Development Center: Tainan, Taiwan, 1982; pp 95-118.

(5) Tymowska-Lalanne, Z.; Kreis, M. The plant invertases: Physiology, biochemistry and molecular biology. In Advances in Botanical Research; Callow, J. A., Ed.; Academic Press: New York, 1998; Vol. 28, pp 71-117.

(6) Sturm, A.; Tang, G.-Q. The sucrose-cleaving enzymes of plants are crucial for development, growth and carbon partitioning. Trends Plant Sci. 1999, 4, 401-407.

(7) Sturm, A. Invertase. Primary structures, functions, and roles in plant development and sucrose partitioning. Plant Physiol. 1999, $121,1-8$

(8) Koch, K. Sucrose metabolism: regulatory mechanisms and pivotal roles in sugar sensing and plant development. Curr. Opin. Plant Biol. 2004, 7, 235-246.

(9) Murata, T. Regulatory properties of sucrose synthetase in sweet potato roots. Agri. Biol. Chem. 1971, 35, 297-299.

(10) Wang, Y.-L. Studies on soluble acid invertase from sweet potato leaves. Master thesis, Graduate Institute of Agricultural Chemistry, National Taiwan University, Taipei, Taiwan, 1995.

(11) Takahata, Y.; Noda, T.; Sato, T. Relationship between acid invertase activity and hexose content in sweet potato storage roots. J. Agric. Food. Chem. 1996, 44, 2063-2066.

(12) Yatomi, M.; Kubota, F.; Saito, K.; Agata, W. Evaluation of root sink ability of sweet potato (Ipomoea batatas Lam.) cultivars on the basis of enzymatic activity in the starch synthesis pathway. J. Agron. Crop. Sci. 1996, 177, 17-23.

(13) Huang, W.-C.; Wang, A.-Y.; Wang, L.-T.; Sung, H.-Y. Expression and characterization of sweet potato invertase in Pichia pastoris. J. Agric. Food. Chem. 2003, 51, 1494-1499.
(14) Wu, L.-J.; Huang, W.-C.; Sung, H.-Y. Partial purification and characterization of soluble acid invertases from sweet potato suspension cells. Food Sci. Agric. Chem. 2000, 2, 49-54.

(15) Liao, Y.-C.; Wang, A.-Y. Sugar-modulated gene expression of sucrose synthase in suspension-cultured cells of rice. Physiol. Plant. 2003, 118, 319-327.

(16) Lehrach, H.; Diamond, D.; Wozney, J. M.; Boedtker, H. RNA molecular weight determinations by gel electrophoresis under denaturing conditions, a critical reexamination. Biochemistry 1977, 16, 4743-4751.

(17) Sung, H.-Y.; Huang, W.-C. Purification and characterization of cell-wall-bound invertase from rice (Oryza sativa) grains. Biotechnol. Appl. Biochem. 1994, 19, 75-83.

(18) Nelson, N. A photometric adaptation of the Somogyi method for the determination of glucose. J. Biol. Chem. 1944, 153, 375380.

(19) Bradford, M. M. A rapid and sensitive method for the quantitation of microgram quantities of protein utilizing the principle of protein-dye binding. Anal. Biochem. 1976, 72, 248-254.

(20) Laemmli, U. K. Cleavage of structural proteins during assembly of the head of bacteriophage T4. Nature 1970, 227, 680-685.

(21) Huang, W.-C. Cloning and characterization of a cDNA encoding vacuolar invertase from sweet potato leaves, and expression of the cDNA in Pichia pastoris. Ph.D. Thesis, Graduate Institute of Agricultural Chemistry, National Taiwan University, Taipei, Taiwan, 2000.

(22) Vijn, I.; Smeekens, S. Fructan: More than a reserve carbohydrate? Plant Physiol. 1999, 120, 351-360.

(23) Ritsema, T.; Smeekens, S. C. M. Engineering fructan metabolism in plants. J. Plant Physiol. 2003, 160, 811-820.

(24) Van den Ende, W.; Michiels, A.; Roy, K. L.; Van Laere, A. Cloning of a vacuolar invertase from Belgian endive leaves (Cichorium intybus). Physiol. Plant. 2002, 115, 504-512.

Received for review November 16, 2004. Revised manuscript received March 8, 2005. Accepted March 15, 2005. This work was supported by grants from the National Science Council, the Republic of China (Taiwan).

JF0480851 